"The Service I am Here for": William Herle in the Marshalsea Prison, 1571

Adams, Robyn

The Huntington Library Quarterly; 2009; 72, 2; ProQuest Art, Design and Architecture Collection pg. 217

\title{
PART 2: VOICES "The Service I am Here for": William Herle in the Marshalsea Prison, 1571
}

\begin{abstract}
This essay examines the letters of the Elizabethan intelligencer and agent provocateur William Herle, written to William Cecil, Lord Burghley, from the Marshalsea prison when the Ridolfi plot was unfolding in the spring of 1571. Imprisoned on a charge of piracy, Herle was drawn into the role of prison spy, a role sanctioned and directed by the Elizabethan authorities and explicitly documented in rich detail in this sequence of letters. Moreover, Herles letters record his experiences of Tudor prison life, offering the modern reader a glimpse of the conditions and layout of the ramshackle Marshalsea. The letters also reveal the prisoners' efforts to circumvent the restrictions of prison life by smuggling letters and objects through the porous membrane of the prison walls. Keywords: espionage in prison, John Lesley, William Herle, Charles Bailly, Ridolfi plot
\end{abstract}

IN THE BRITISH LIBRARY COTTON COLLECTION can be found a mesmerizing sequence of a dozen letters written by William Herle from a dank prison cell in the spring of 1571 . These letters testify to his clandestine involvement in the Elizabethan government's efforts to uncover and penetrate the secret machinations of the figures involved in the Ridolfi plot, a major Catholic conspiracy to overthrow Elizabeth. ${ }^{1}$ Letters of this kind rarely survive in the historical record, and Herle's accounts of his trickery while spying for the authorities-a desperate attempt to secure his freedom-are compelling and chilling in equal measure. Many of the letters are substantially frayed at the edges and in the sort of condition generally that betrays their provenance, hastily written on cheap, illicitly procured paper and then stuffed into damp corners to evade

1. For biographical information on William Herle, see Oxford Dictionary of National Biography, http://www.oxforddnb.com.catalogue.ulrls.lon.ac.uk:8o/view/article/37536 (accessed 14 August 2008). For the entire corpus of Herle's extant letters in English, see "The Letters of William Herle," ed. Robyn Adams, Centre for Editing Lives and Letters, 2006, http://www.livesandletters.ac.uk/herle/ index.html. The letters detailing Herle's involvement in the plot are located in the British Library [hereafter BL], Cotton MS. Caligula.C.iii), and in The National Archives in the Scottish State Papers (TNA, SP 53/6).

Pp. 217-238. @2009 by Henry E. Huntington Library and Art Gallery. ISSN 0018-7895 | E-ISSN 1544-399x. All rights reserved. For permission to photocopy or reproduce article content, consult the University of California Press Rights and Permissions website, http://www.ucpressjournals.com/reprintInfo.asp. DOI: 10.1525/hlq.2009.72.2.217.

HUNTINGTON LIBRARY QUARTERLY | VOL. 72, NO. 2 
scrutiny. The letters offer insight into a specific three-week period when this infamous plot was unfolding, and they raise provocative questions about the circulation of letters both within the prison and between the prison and the outside world.

Unlike many prison letters of the period, Herle's are not self-reflexive accounts of personal hardship or protestations of innocence. His letters provide an alternative perspective to that of the dyadic prison correspondence conducted in more conventional situations, of which many corpora survive; yet Herle adheres to the customary epistolary formulae and codes expected of an early modern letter writer addressing his patron. ${ }^{2}$ Herle's status as an agent provocateur and his deployment by politically potent figures gave him a peculiar position in relation to the social landscape, one that he hoped to exploit in order to extricate himself from a potentially dangerous situation and to improve his unsavory reputation.

Herle's involvement in the tangled Tudor intelligence operation surrounding the Ridolfi plot makes a valuable contribution to our understanding of the Elizabethan network of informers and the place of prison spies within this network. In this article, I examine the way in which the correspondence Herle wrote from inside his prison cell can provide an insight into how the Elizabethan government responded to plots to overthrow the sovereign, using whatever means were at their disposal to carry out surveillance. I will also consider the pragmatic methods used by prisoners to smuggle objects and letters between, over, and through the physical barriers of the prison.

The entire corpus of Herle's letters, spanning the years $1559-88$, is remarkable not only for highly sensitive political content but also for epistolary strategies designed to enhance Herle's patronage relationships. ${ }^{3}$ The recipients of his letters included Lord Burghley, Sir Francis Walsingham, and the Earl of Leicester, to whom Herle sent diverse information, often linked to requests for advancement. His was a heterogeneous career, veering from unofficial work as an envoy in the early 1560 s to the piratical activity that resulted in the period of imprisonment in 1571, and turning again toward intelligencing and diplomatic legation from the 1570 s until the end of his life. His success seems to have rested upon his linguistic skills and his propensity for recording information in prolix detail.4 His extant correspondence, collected and deposited in English archives relating to state matters, reveals distinct sequences of intelligence activity.

2. Deborah E. Harkness describes the energetic scribal activity in the notebooks of Clement Draper, imprisoned in the King's Bench prison for debt in the late sixteenth century, who over the thirteen or so years of his incarceration recorded details of encounters with his fellow inmates, scientific and medical practices, and reports of news from the outside world; see Harkness, The Jewel House: Elizabethan London and the Scientific Revolution (New Haven, Conn., 2007), 181-210.

3. For intelligence letters, and recent wider studies of epistolarity, see Alan Stewart, Shakespeare's Letters (Oxford, 2008), esp. chaps. 1 and 7; and Gary Schneider, The Culture of Epistolarity: Vernacular Letters and Letter Writing in Early Modern England, 1500-1700 (Newark, N.J., 2005), esp. chap. 4.

4. Herle was able to write Latin and French and understand Dutch and Italian. 
Herle's experience with merchant activity and the commercial credentials he acquired in the service of the cloth merchant Sir William Garrard afforded him a level of mobility that enabled him to gather sensitive information both at home and abroad. This information could range from reporting the whereabouts and movements of suspicious individuals to gathering local information and news. In the early years of Elizabeth's reign, and prior to this spell in prison, Herle was called upon to perform undercover duties while acting as a factor to Garrard, and it was during these journeys that he refined his intelligence skills. 5 Herle was required by his impecunious circumstances-he had no formal or official employment-to seek alternative means of subsistence, drawing loans from friends and moneylenders to cover his debts; unable to repay, Herle spent frequent stretches in the London debtors' prisons. The letters and documents that I will examine in this essay, a sequence dating from November 1570 to the summer of 1571, suggest another dimension to what is essentially an opportunistic yet modest career based on the exchange of valuable information at politically sensitive moments.

This episode relating to Herle's imprisonment began with a directive from the Privy Council in mid-November 1570 . The Council commanded that Herle and three others be put into the custody of the knight marshal, supervisor of the Marshalsea prison, to be kept in solitary confinement under accusations of piratical activity off the Isle of Wight. ${ }^{6}$ By January, Herle had written to the lord keeper, Sir Nicholas Bacon, to protest his innocence, stating that no charges had yet been brought against him. He insisted that his incarceration was a result of unfounded and malicious rumor:

some ill suggestion made to the right honorable Councell, caused them to send for me \& for certain other abowtt the wight addressing their letters to master horsey, whereupon I was committed from Hampton Cowrt the 14th of November last to close prison here, where I remain this long no less miserably consumed, than both unheard \& unpittied, \& withall no due cause to be objected unto me.7

With this letter, Herle enclosed an account or petition (no longer extant) of his movements for the prior six months to prove his innocence and a careful and cautiously worded offer of service to the state, presented to "mi Lords of the Cowncell in the sayd petycion som servyce (havyng their good oppinion \& cowntenance) which shalbe of importance to her Majestie \& without charge to ani." 8 By 4 April, after a three-month

5. For biographical information on Sir William Garrard, see $O D N B$, article 37441 (accessed 31 March 2009).

6. Acts of the Privy Council of England, ed. J. R. Dasent, vol. 7, 1558-70 (London, 1893), 401. This accusation of piracy followed another period of imprisonment and investigation for piracy in 1565; see The National Archives, State Papers (hereafter TNA, SP), 15 12/76, fols. 219r-22v; and TNA, SP 15 12/76.i, fols. 224r-26v. The first document (SP 15 12/76) is a letter to Burghley explaining his movements around the coast of Kent and denying his involvement in piratical activity. With this letter Herle enclosed a diary of his movements for the period in question (the month of July), now SP 15 12/76.i.

7. Herle to Sir Nicholas Bacon, 8 January 1571 (TNA, SP 12 77/1, fols. 1r-2v).

8. Ibid., fol. 1 verso. 
delay, it seems that the Council had taken Herle up on his offer. In a letter addressed to Lord Burghley, Herle protested that the restrictions on his liberty within the prison precincts were preventing him from making useful contacts:

Butt towching the servyce I am here for, the tyme consumes and I do nothyng \& the liuetenant hath no warrant to suffer ani accesse unto me, nor somuche as paper and inck unles I will write to your Lord or the Cowncell whereby the cheeff purposes do decaye, ffor if in this beginneng I do nott entertayne a wise oppinion with mi cawses abrode, I mar all. 9

Eager to perform the cryptic "service" he alludes to, Herle then revealed that the purport of his "mission" in the Marshalsea was to act as an intermediary:
Desiring your Lord that I may speak to you tomorrow myself, for that I have sundry things to say unto you by mouth, and this my open bringing to the court will make the better opinion of me with the Bishop, and lastly that I may have the keeper of the Marshalsea and my man to repair unto me, whereupon rests my greatest enterprise, and to understand your Lords pleasure whither I may certify the Bishop that I was exam- ined if I had ever access unto him, or whether ever I practised between Charles and him either by letters or messenger. ${ }^{10}$

By unpacking these abstruse requests, and from what we know of the complex development of events, we can infer that the "service" Herle was to perform (no doubt in exchange for removing the threat of prosecution and punishment for the original charge of piracy) had been shaped by Burghley, and that Herle was now to inveigle his way into the confidence of selected prisoners in order to ferret out political information. By being conspicuously summoned for interview, Herle could prove his "credentials" as a suspicious individual, and by setting up a rudimentary channel of communication engaging his manservant and the keeper of the Marshalsea as his inside contacts, Herle could begin to construct the framework required to elicit the information required by the Tudor authorities. Herle claimed that this would be easily effected, describing his target, "Charles," as "ferefull, full of words, glorious and given to the cup," and boasting that he had already wormed his way into the trust of this prisoner, "over whom I have already won some good degree."11

Herle's letter apparently alludes to an unofficial communication network operating in the Marshalsea, to which he requested access-suggesting that the system was in part conducted or regulated with the knowledge of the prison guards and of govern-

9. Herle to Burghley, 4 April 1571 ( BL, MS. Cotton Caligula.C.iii, fol. 6or-v).

10. Ibid.

11. Herle to Burghley, 11 April 1571 (BL, MS. Cotton Caligula.C.iii, fols. 61r-62v). 
ment ministers intent on penetrating the secrets of their political prisoners. A prisoner's access to an unofficial or illicit system of communication within the prison walls depended in part on the reason he was incarcerated.

The Marshalsea was a crumbling and insecure complex of buildings housing an assortment of prisoners indicted and remanded under the administration of the Court of Westminster. For ordinary prisoners, license to leave the grounds temporarily could be obtained on production of a bond; such excursions often required a prison escort. ${ }^{12}$ Prisoners accused of religious and political offenses were likely to be confined to "close prison," either to prevent escape or to limit and control access. Indeed, the Marshalsea, located in Southwark, was one of the chief holding prisons for Catholics and those who had committed specific maritime offenses such as piracy. ${ }^{13}$ It makes sense that in a prison primarily employed for the detention of political prisoners, the Elizabethan government would have at least a rudimentary system of information gathering in place, whereby detainees could barter details about the political prisoners to enhance their own prospects. Herle's letters go some way toward illustrating the workings of this system, indicating the physical route letters took between the Marshalsea and the outside, and providing a partial census of the prisoners and their regular visitors. In the spring of 1571 , the political prisoners detained in the Marshalsea included one of the figures mentioned by Herle in the above letter, "Charles." He was suspected of involvement in the Ridolfi plot to overthrow Elizabeth.

In response to the failure of the Northern Rebellion of 1569 and the furious Protestant reaction to the Papal Bull of Excommunication (Regnans in Excelsis) the following year, Rome, with Spanish support, continued to foster and finance conspiracies to restore Roman Catholic power in England by placing Mary Stuart (at the time

12. Prior to his agreement with Burghley to "decipher" Bailly, Herle had traveled to Essex to secure a wanted felon, James Chillester; Herle to Burghley, 19 March 1571 (BL, MS. Lansdowne 13, fols. 162r-164v).

13. Charles Nicholl, The Reckoning: The Murder of Christopher Marlowe, and ed. (London, 2002), 159. The Marshalsea, like most of the London prisons, also held debtors. Prisoners remained locked up only until they went to trial: the idea of a custodial sentence did not emerge until the late sixteenth century. See John H. Langbein, "The Historical Origins of the Sanction of Imprisonment for Serious Crime," Journal of Legal Studies 5 (1976): 35-60 at 39; Pieter Spierenburg, The Prison Experience: Disciplinary Institutions and Their Inmates in Early Modern Europe (Amsterdam, 2007), 7-8, 15-16; and Joanna Innes, "Prisons for the Poor: English Bridewells, 1550-1800," in Labour, Law, and Crime: An Historical Perspective, ed. Francis Snyder and Douglas Hay (London, 1987), 42. Studies of the Marshalsea prison are limited and insubstantial, and focus for the most part on the context of Dickens's Little Dorrit. Those that concentrate on the history and conditions of the Marshalsea include Survey of London, vol. 25, St. George's Fields, the Parishes of St. George the Martyr, Southwark and St. Mary, Newington, ed. Ida Darlington (London, 1955), 7-9; and W. Eden Hooper, The History of Newgate and the Old Bailey (London, 1935), 152-53. For a survey of the Court of the Marshalsea, see D. G. Green, "The Court of the Marshalsea in Late Tudor and Stuart England," American Journal of Legal History 20 (1976): 267-81. On London prisons more generally, see Bruce Watson, "The Compter Prisons of London," London Archaeologist 7 (1993): 115-21; Clifford Dobb, "London Prisons," Shakespeare Survey 17 (1964): 87-100; and Edward Douglas Pendry, Elizabethan Prisons and Prison Scenes, Salzburg Studies in English Literature: Elizabethan and Renaissance Studies 17, 2 vols. (Salzburg, 1974). 
imprisoned in Sheffield castle) on the throne. Roberto Ridolfi, a Florentine merchant from an ancient banking family, who had been used as an agent by the authorities in Rome and to whom the infamous bull had first been sent for distribution in London, was now involved in devising a plan to depose Elizabeth. Spanish troops were to be requested from the Duke of Alva, who would join up with Catholic supporters in England, attack London, take Elizabeth hostage, and place Mary on the throne with an English husband, the Duke of Norfolk. In forwarding the plot, Ridolfi communicated with Mary's adviser John Lesley, the bishop of Ross (the "bishop" to whom Herle refers in the previous quotation), sending secret plans containing ciphered messages between the Continent and England. ${ }^{14}$

In early April 1571, the bearer of one of these messages, Bailly, who was a servant of Lesley's, was stopped on his journey from Brussels at the port of Dover under suspicion of carrying treasonous material in his luggage. Arrested by the deputies of Lord Cobham, warden of the Cinque Ports, Bailly was removed to Cobham's house at Blackfriars in London, and his traveling trunk containing contraband books and letters was seized by his captors. After examination by Cobham, Bailly was entrusted to the custody of Legot, a porter of the Marshalsea prison, who on 13 April placed him in a cell, within whose precincts William Herle was waiting, ready to set in motion the plan devised between Burghley and himself. ${ }^{15}$

The earlier letters in this sequence demonstrate Herle's sedulous preparation, during which he endeavored to leave a visible trail that marked him as a bona fide prisoner, "enduring" frequent examinations before the Council, and returning to the Marshalsea under solitary confinement. Herle and Burghley (whose participation is naturally now silent) constructed a plan in which Herle would offer to act as a conduit between Lesley and Bailly, delivering their enciphered letters (written in French) to each of them, and secretly diverting the correspondence via Burghley for surveillance and copying. As Francis Edwards notes, Herle was expected to find out the key to this cipher, not just so Burghley and his agents could read the furtive correspondence, but also should they wish to add to the contents. Edwards also claims that

14. For a thorough (although biased) account of the Ridolfi plot, see Francis Edwards, SJ, The Marvellous Chance: Thomas Howard, Fourth Duke of Norfolk, and the Ridolphi Plot, 1570-1572 (London, 1968). For a detailed account of Ridolfi's involvement, see Geoffrey Parker, "The Place of Tudor England in the Messianic Vision of Philip II of Spain: The Prothero Lectures," Transactions of the Royal Historical Society, 6th ser., 12 (2002): 167-221, esp. 185-94. Other sources for this plot and events leading up to it include John Guy, "My Heart is My Own": The Life of Mary, Queen of Scots (London, 2004), chap. 28, esp. pp. 460-65; J. E. Neale, Queen Elizabeth I (London, 1971), 194-203; Penry Williams, The Later Tudors: England 1547-1603 (Oxford, 1995), 260; and Wallace T. MacCaffrey, Elizabeth I (London, 1994), chap. 12, esp. p. 138. William Murdin reproduces selected letters between conspirators in the Ridolfi plot in the first pages of his letter collection, A Collection of State Papers Relating to Affairs in the Reign of Queen Elizabeth from the Year 1571 to 1596 (London, 1759). David Mckeen has a small section on Lord Cobham's involvement in the plot in A Memory of Honor: The Life of William Brooke, Lord Cobham (Salzburg, 1986). The consensus is that Ridolfi was probably a double agent working for Walsingham; see Edwards, Marvellous Chance, 30.

15. For Ridolfi, see $O D N B$, article 23634; for Bailly, article 1058; and for Lesley, article 16492 (all accessed 14 August 2008). 
Herle's requests for guidance on the delicate enterprise "reveal the limited extent of Herle's imagination, and also the completeness of his dependence on Cecil":16

moreouer it may plese your Lord to wryte me or cawse master Blithe to do it whatt artycles I shall saye that I was examined uppon by the Cowncell, that I may be throwly armed, lest he perceue a further halltyng in the matter than before. ${ }^{17}$

Thus, finding himself imprisoned in the Marshalsea and undertaking Burghley's subterfuge as a route to liberty, Herle seized the opportunity to spy on Bailly and to intercept his letters. He followed Burghley's instructions with as much fervor as he could muster in a damp prison cell, and he earnestly began researching and compiling information on which he could question Bailly. His brief was to "discover" the cipher used between Lesley and Bailly in their secret correspondence and to elicit any additional information about Ridolfi and the Italian financiers' plot to dethrone Elizabeth.

Yet the conclusion that Herle's assignment preceded Bailly's imprisonment is thrown into question by the contents of a letter written about a week after the one quoted above, in which Herle appears to describe Bailly as if unknown to him before:

There is on committed yesternight to the marshallsea, whose name is Charlles and pretendes to be a Brabander borne at Bruxelles, but indede I vnderstand hym to be a scott and a minister to the Bishop of Rosse, of whom grett thyngs might be drawen, if he had bin a close prisoner, for it is a dangerows fellow, and conteynes a whole masse of their secretts, but now he is verey tymerows, vppon which poynt the more might be wrought if he were alone. ${ }^{18}$

Compared with the confidence of Herle's later strategies to convince Lesley of his fidelity, and the queries about constructing his own cover, the tone of this description of Charles Bailly is curiously tentative and suggests that Herle did not have advance warning of his arrival. Herle's tonal register has altered perceptibly to that of description, as he apparently introduces Bailly to Burghley and seems unaware of the reasons for his incarceration. Is it possible to detect here a different epistolary trajectory from that of the former letters, in which Herle described in detail the method he would pursue to elicit secret information from Bailly and Lesley, the reasons for whose imprisonment he knew full well? Perhaps Burghley had in mind a more public readership for

16. Edwards, Marvellous Chance, 42, 45.

17. Herle to Burghley, 4 April 1571 (BL, MS. Cotton Caligula.C.iii, fol. 6or-v). Offers to spy on prisoners were not uncommon; see Robert Hammond (alias Harrison) to Lord Burghley, November 1591 (BL, MS. Lansdowne 99, fols. 163r-164v); Hammond asked Burghley to: "vouchsaffe to ymploy me in some prison for the discoverie of the papists practises, or for Spaine, France, Italie, or anie other place."

18. Herle to Burghley, endorsed by a later hand as "c. 10 April 1571" (TNA, SP 53/6/36, fols. 62r-63v). 
this letter, in which Herle describes Bailly's committal. That readership is now lost to view, but if so, the letter's apparent innocence might suggest that Herle's position as spy within the Marshalsea, and crucially, working directly for Burghley, was until its writing known only to a select few. ${ }^{19}$ Burghley's design may have been for Herle to appear to be offering this information without any prior briefing, possibly for reasons of diplomatic or ethical protocol, or perhaps to avoid alerting counter-surveillance.

In the same letter, Herle revealed that he was ready to divulge intelligence to Burghley:

This day on that is a skott of my acqwaintance was sent to hym from the Bishop of Rosse with instructyons, by whom haply I cowd lerne somwhatt, as happy is he that in suche wretched practises do ani service to his Prince and State, wherof it may plese your Lord to lett me vnderstand your will furthwith. ${ }^{20}$

The modified tone and content of the letter suggest that only a few others-possibly the keeper of the Marshalsea alone-were aware of Herle's prior arrangement with Burghley. Indeed, reading Herle's references to Bailly and Lesley in his letter of 4 April, before Bailly had even arrived in England, it would seem that Burghley was expecting him and had already arranged for his arrest. Edwards suggests that Burghley had been tipped off by William Sutton of Bailly's imminent departure from the Continent; Alan Haynes is confident that Sir Francis Walsingham, resident in the English embassy at Paris, had identified Bailly and notified Burghley of Bailly's impending journey to England. ${ }^{21}$ This advance warning of his arrival, and the availability of men like Herle to act as agents provocateurs within the prison environment, tend to confirm that there were mechanisms of intelligence-gathering activity within the Elizabethan administration. ${ }^{22}$

19. This letter may have been intended to be shared with members of the Privy Council, by whose directive Herle had initially been imprisoned, or might have been written at the instruction of Burghley to create a written record of the offer to spy on the correspondence between Bailly and Lesley.

20. Herle to Burghley, 10 April 1571 (TNA, SP 53/6/36, fol. 62r).

21. Edwards, Marvellous Chance, 38; Haynes, in Walsingham: Elizabethan Spymaster and Statesman, (Sutton, U.K., 2004), suggests that "given his position in Paris, then the hub of espionage, it seems realistic to suggest that Walsingham had been given his name and in turn had contacted Burghley" (p. 17).

22. Recent research on the application of sensitive information and intelligence to conciliar networks and the Elizabethan polity includes Patrick Collinson, "Servants and Citizens: Robert Beale and other Elizabethans," Historical Research 79 (2006): 488-511; Natalie Mears, Queenship and Political Discourse in the Elizabethan Realms (Cambridge, 2005); and Mark Taviner, "Robert Beale and the Elizabethan Polity" (PhD diss., University of St. Andrews, 2000). For Elizabethan intelligence networks, see Paul E. J. Hammer, The Polarization of Elizabethan Politics: The Political Career of Robert Devereux, 2nd Earl of Essex, 1585-97 (Cambridge, 1999); Curtis Breight, Surveillance, Militarism, and Drama in the Elizabethan Era (London, 1996); John M. Archer, Sovereignty and Intelligence: Spying and Court Culture in the English Renaissance (Stanford, Calif., 1993). For a detailed study of the intelligence networks and the processing of information relating to Burghley, see Stephen Alford, Burghley: William Cecil at the Court of Elizabeth I (New Haven, Conn., 2008). 
Burghley's strategy appears to have been for Herle to communicate with Lesley via a Scot called William Barthlett (possibly the "skott" of Herle's acquaintance), who, according to Herle, was providing board and lodging to Herle's servant. After Bailly's close imprisonment on 16 April, Herle was required to set up a rudimentary lettercarrying system in which he would give his servent the letters he had collected from Bailly. Herle's servant or Barthlett would then convey them to Lesley. Herle related his encounter with Bailly with confidence:

Butt now reqwireng my ayd, I told hym yf [Bailly] wold vse fidelity and secresy, I wold hasard mi pore fortune to conveye polytyckly ether messaige or letter vnto hym [Lesley], wheruppon with grett contentment he departed, menyng to retorne tomorow, beside that his oppinion is suche of me, as he is to be perswaded to ani thyng. ${ }^{23}$

Despite Herle's urgent suggestion that Bailly instigate correspondence with his associates, Lesley and Bailly were, quite reasonably, wary of Herle's offer to forward the letters, Bailly preferring to wait for his confederates to initiate the correspondence. Herle was obliged to try to accelerate matters, emphasizing that time was pressing and reminding Bailly that his offer of access to a system of communication while in prison was a luxury. He wrote to Burghley informing him that he had offered Bailly paper and ink to begin his correspondence but that the prisoner was hesitant:

He wold haue som of his fellowes wryte first, whervnto I sayd that tyme most work that, butt in hym, for that I cowd not tary ani longe talke for the danger which was grett, he most vse tyme and occasion as they were presented to hym, a felicity that hapnes seldom to men in his Case, wherwith he was contented. ${ }^{24}$

The two correspondents were reluctant to entrust their ciphered letters to a stranger. To counter this, Herle touted an alter ego of a disaffected agitator, arranging for an unflattering description of himself to be given to Lesley's followers by Burghley when they were examined by the Council. This portrait was reported back to him by Malachias, another prisoner in the Marshalsea connected to Lesley, who had recently been examined before Burghley:

For the speche your Lord had of me, it was passingly handled, confirmeng his oppinion the more than euer it was beffore, for sayth he to me, you ar in extreme ill conceytt with the Lord of Burghley, bothe to be a prodigall man, withowt governement, having good parts and abusing

23. Herle to Burghley, 16 April 1571 (TNA, SP 53/6/40, fols. 69r-7ov).

24. Herle to Burghley, 18 April 1571 (BL, MS. Cotton Caligula C III, fols. 176r-77v). 
them vtterly, And that John poole and you wold have betrayed the Cardinall and have becom Pirates at the seas. ${ }^{25}$

Burghley's description of Herle had no doubt been prepared in advance, but a later profile sketched by Lesley appears to have come from an impartial and independent source. Herle commented that Lesley had

ciffted me mani wayes, and enquired of me abrode, butt the generall oppinion is that I am a discontented man and factyows, which Ioyned with mi trobles doth perplexe his other suspicyons, as he is certayn in non of them, driveng him to the vttermost corner of his witt. ${ }^{26}$

That there were independent reports about Herle circulating in London shows that Herle's marginal and penurious status was well suited to this clandestine enterprise. Yet it must have been unnerving for Herle to voice these disagreeable portrayals with his own pen, despite their purportedly fictive nature. It is nonetheless possible to detect a note of relish when Herle describes the measures taken to convince the prison population of his allegiance. He reported to Burghley, "I tooke a payer of shackells yesterday of purpose, whiles I went into the garden \& that hath astonied the Scott and all those of the house mervaylously." 27

To complement his assumed character as a malcontent, Herle required seditious and illegal paraphernalia to convince his targets. Five days after his arrival in the Marshalsea, the querulous Bailly made a request for some comforting reading matter. Herle immediately wrote to Burghley that he had asked for

the lone of some frenche booke, which I promised, butt I haue non here butt the psalmes and service of the refformed religion, and that may brede mi discredite with hym, if it might plese your Lord therfore bi this berer to send me som story or prayer that may serue the torne, which shalbe reserued for you agayn. ${ }^{28}$

Conscious that his cover would be blown if he were to supply Bailly with his own Protestant devotional literature (it is surprising that he had kept it with him), Herle was also aware that a supply of Catholic material would further cement Bailly's allegiance. Significantly, Herle promised the return of the illegal material after he used it to

25. Herle to Burghley, 19 April 1571 (BL, MS. Cotton Caligula C III, fols. 178r-81v). The Oxford English Dictionary Online (hereafter OED) defines "passingly" as "surpassingly, pre-eminently; exceedingly, extremely," http://o-dictionary.oed.com.catalogue.ulrls.lon.ac.uk/cgi/entry/50172480? (accessed 14 August 1008).

26. Herle to Burghley, 29 April 1571 (TNA, SP 53/6/53, fol. 89r-v).

27. Herle to Burghley, 27 April 1571 (BL, MS. Cotton Caligula.C.iii, fol. 69r-v).

28. Herle to Burghley, 18 April 1571 (BL, MS. Cotton Caligula.C.iii, fols. 176r-77v). 
deceive Bailly, a demonstration of his obedience and religious fidelity that is surprising in this context of illicit entrapment-or perhaps Herle was looking to his future role in the service of Elizabeth.

\section{丳}

How were these books and materials smuggled into the prison and kept hidden from the authorities? Herle's letters from this period provide a record of the methods used by the prisoners to circumvent surveillance (although it is likely that the prison keepers were aware of some of the illicit materials, and possibly even encouraged their dissemination), a record that also gives us useful information about the layout of the prison and Herle's own spatial situation in it. Information about the floor plan and arrangement of the Marshalsea compound, since the buildings no longer survive, is scarce, and Herle's graphic description is all the more valuable for the information he provides about how the prisoners attempted to overcome (in epistolary terms) the physical boundaries of that environment.

Herle's letters record with a note of satisfaction his efforts to persuade Bailly and Lesley that he was loyal to them, and that he was, like them, under the government's surveillance. He recounted with relish his efforts to win Bailly's trust:

Abowtt midnight mi Lord, I cam to Charlles chamber dore, alledging that the gentillman his neighbor was haply com that night to lye in his Chamber, which had opened the occasyon to me so to haue free accesse vnto hym ... yett tellyng hym that I had a letter for hym, cowd nott finde it in the darke and durst nott seke it for my chamber Fellowes, which vnhaply I had forgotten to putt a part beffore night, wheratt he was mportunate to haue it by and by, butt I told hym there was no remedy tyll the mornyng. ${ }^{29}$

The letters reveal that Herle was confident in his role but that Lesley continued suspicious. Herle announced to Burghley that he was on the verge of getting closer to his quarry than any prison spy before him:

If the matter may be so handled as I appeare giltles, I shalbe able to creepe further into his grace, then any of my sorte ever did which proceeding is so vsed of my side (I speake it modestly) as bothe in the purpose and direction in every motion that my self or my man proceedes by noe one jot can be espyed. 30

29. Herle to Burghley, 24 April 1571 (TNA, SP 53/6/48, fol. 82r-v).

30. Herle to Burghley, 1 May 1571 (BL, MS. Cotton Caligula.C.iii, fol. 72r). "Guiltless" is glossed in the OED as "Having no acquaintance, dealings, or familiarity with, no experience or use of"; http://o-dictionary.oed.com.catalogue.ulrls.lon.ac.uk/cgi/entry/50100124? (accessed 30 March 2009). 
Herle's muscular claim that "noe one jot" of his actions could be "espyed" was designed to assure Burghley of continued results from his surreptitious activity. Yet not only was Herle required to evade suspicion from his intended targets, he was also obliged to circumvent the attempts of the prison staff to limit illicit behavior. Because his identity as agent provocateur needed to be concealed from the intermediate officials and lowerranking staff of the Marshalsea to prevent the exposure of the project, Herle was as much constrained by surveillance as his fellow inmates were.

Yet the initiative of the prisoners and the corruptibility of the guards ensured that the security measures surrounding even close prisoners could usually be circumvented. Letters and other items could be distributed with a little imagination. Thus Herle's arrangement with Bailly and Lesley was convenient for them, providing mutual access, while the encoding of the letters apparently guaranteed a certain degree of privacy and a safeguard against Herle's prying eyes. However, ciphered letters could present their own obstacles to efficient communication. One week after Bailly's incarceration in the Marshalsea, Lesley confirmed that he had managed to retrieve the ciphered letters from Ridolfi as well as the cipher alphabet. (At this point Lesley was not in close prison but under "house arrest.") ${ }^{31}$ However, although he had the key to unlocking the cipher, he was unable to crack the code: "I have recovered all your Letters and the Alphabet, but cannot discyphre them, therfoir I pray you wreit to me as soone as you can some Instructions to do the same."32

Finally plucking up the courage to deploy Herle as a messenger a week after his incarceration in the Marshalsea, Bailly explained in detail to Lesley how the transfer of letters could be effected:

My chamber where I am prisoner doth open vpon the streete and vnder the wyndowe ther ys a lyttel house of som poore man. Almost in the topp of the house inwarde, ther is a hole that comith to my chamber, wherin I may easely thrust my hand. I think that with a small mater, George Robinson or borche might gett acqayntance with the poore man, and by that meane throughe the hole might be conveyed to me any letters, or else I might easely speake to any body, yf they wold com into the streate or place. I shew my selfe at the windowe at viij of the clock in the mornyng, and At noone, at after dynner at iiij of the clock, and in the evening betwene seven and eight. There is allso a lyttle Tauerne wher all men resort vnto. 33

31. See Rosalind K. Marshall, "Lesley, John (1527-1596)," ODNB, article/16492, accessed 29 May 2009.

32. Lesley to Bailly, 20 April 1571 (H[istorical] M[anuscripts] C[ommission], Cecil Papers 5/110); reprinted in Murdin, State Papers ... in the Reign of Queen Elizabeth, 6.

33. Bailly to Lesley, 20 April 1571 (HMC, Cecil Papers 5/108). Burghley has endorsed the original ciphered letter, "The first letters from Charles to the Bishop out of the Marshalsea, 2oth April" (HMC, Cecil Papers 5/114). The letters between Lesley and Bailly delivered by Herle are in the Cecil Papers at Hatfield House. They were deciphered and translated contemporaneously, possibly even by Herle in his prison cell; see Herle to Burghley, 26 April 1571 (BL, MS. Cotton Caligula.C.iii fol. 68r-v). 
Bailly's plan was to push or receive letters through the hole into the attic of his neighbor, which would then be conveyed to Lesley by a selected messenger. Implicit in this option is that there was no need to entrust any material to Herle, of whom they were still deeply suspicious. In the letter quoted above, Bailly recommended Robinson, or "Borche," but it was crucial for Burghley's strategy that letters pass through Herle's hands first. Somehow, Herle had to ensure that he was the only point of collection and deposit from Bailly, so that no letters escaped contact with Burghley. He had suggested to his patron soon after Bailly's incarceration that Bailly be committed to close prison, and that by means of a secret "token" with the keeper, Herle would be permitted access to Bailly, stating baldly, "I hope to discover ani parte that is in hym."34

Burghley's simple plan of using Herle as the intermediary between Bailly and Lesley was contingent on Herle's diversion of the letters to Burghley to be copied, then collecting and forwarding them to their originally intended recipient. Herle explained to Burghley his arrangements for exchanging the letters with Lesley:

The sayd Barthlett might repayre vnto me, with messaiges from tyme to tyme, and to be the mowth bettwen Charlles and hym, which this way might be don clenly, and voyd of all suspicyon. 35

Herle realized that he would have to convince Barthlett that his loyalties lay with Lesley. He reported to Burghley that he had informed Barthlett

that nether Charles was racked, nor likely to be racked, which speche of myne was uttred in suche pyteows forme, myne Irons gingling up and downe by mete occasions, as the fellow wept $\&$ sobbed, having indede confirmed the Bishop by the hering of myne irons the first time, in a more assured oppinion of mi trust. ${ }^{36}$

It would seem from Herle's emphatic insistence that they employ his services that Bailly and Lesley had other options available for a system of communicationtestifying to the permeability of the prison environment in general. Herle's accounts of the dispatch and collection of these letters are arrestingly vivid, and he apparently took grim pleasure in reporting the more spectacular episodes:

Now this mornyng knowing whatt tyme [Bailly] shold com furth I conveyed mi sellf secrettly beffore into the privey in the gardein, where I delyuered hym the Bishops letter, who with grett Ioye receving it, promised answer in thaffter noone... repaireng in the affter noone to Axe alley, 37 where he cast me owtt of the grate an answer to the Bishops letter, which I

34. Herle to Burghley, 11 April 1571 (TNA, SP 53/6/37, fols. 64r-65v).

35. Herle to Burghley, 18 April 1571 (BL, MS. Cotton Caligula.C.iii, fols. 176r-77v).

36. Herle to Burghley, 29 April 1571 (TNA, SP 53/6/53, fol. 89r-v).

37. Axe Alley may be in the environs of the Axe and Bottle Inn, located near the Marshalsea precinct. See John Strype, A Survey of the Cities of London and Westminster, ed. Julia Merritt (University of Sheffield, 2007), http://www.hrionline.ac.uk/strype/TransformServlet?page=book4_o29. 
present herewith and menyng to have caste vp a letter of myne owne, whose copi is here. ${ }^{38}$

Quite apart from these details about the layout of the Marshalsea, this extract reveals the kind of clandestine behavior frowned upon by the prison authorities, but which they could do little about:

\begin{abstract}
Also I was espied by a bakers wife who obiected to me ytt cowd be no honest matter that I offred in so vnffytt a place, which she wold declare vnto the keper, butt I gave the best words I cowd, and so departeng delyuered the sayd letter vnder Charles stayres dore to hys own hands, who within a whyle after delyuered me an answer to the same, which also I have here with me.39
\end{abstract}

It was not only the prisoners who were subject to intense scrutiny: their visitors and correspondents were often under suspicion and very closely observed as well. The Elizabethan polity was keen to restrict the visitors to political prisoners. $4^{\circ}$ One of Lesley's questions to Barthlett during the early stages of Bailly's imprisonment revealed Lesley's own intelligence strategies. Herle reported in a letter to Burghley that Barthlett had inquired of him whether any of Lord Cobham's men were currently monitoring Bailly's visitors. ${ }^{11}$ Indeed, the day after this report to Burghley, a man named Melchior (secretary to the Spanish ambassador) and Robert Mackinson (a follower of Lesley), both frequent visitors to Bailly, were imprisoned in the Marshalsea for trying to visit him secretly. ${ }^{42}$ This was an unexpected bonus for Herle, who could foster their indignation and encourage their furious protests against Elizabeth's administration. $43 \mathrm{He}$ wrote approvingly to Burghley, who had moved to limit Bailly's access to his associates by placing him in solitary confinement:

The keper of this place mi Lord, hath receved your warrant for Charlles close imprisonment, and for the staye of all suche as desire to speke with hym, who is to execute his charge as zelowsly as truly, for that he wisely forseeth the matter by the importance of the words to towche the state, which Charlles hath bin visited all this daye of a grett sight of his fellowes, tyll a lyttell before your Lords warrant. 44

38. Herle to Burghley, 24 April 1571 (TNA SP 53/6/48, fol. 82r-v).

39. Ibid, fol. 82r.

40. The restriction of personal visits would encourage alternative routes of communication, such as letters, which could then be intercepted and used to the government's advantage.

41. Herle to Burghley, 18 April 1571 (BL, MS. Cotton Caligula.C.iii, fol. 176r).

42. Alford, Burghley, 170.

43. For the arrest/imprisonment of Melchior and Robert Mackinson, see Herle to Burghley, 19 April 1571 (BL, MS. Cotton Caligula.C.iii, fols. 178r-81v); Edwards, Marvellous Chance, 56; John Lesley, diary from 11 May 1571 to 18 October 1571 (BL, MS. Cotton Caligula.C.iii, fols. 2r-39v).

44. Herle to Burghley, 16 April 1571 (TNA, SP 53/6/40, fol. 69r). 
Yet, just as there were methods of eluding official scrutiny within the prison confines, measures were taken by the conspirators to placate and confuse their keepers. Lesley pretended to the authorities that he was barring his doors against unsavory visitors. Barthlett informed Herle that Lesley had declared that he would refuse access to all visitors, regardless of whether they were "English" or "stranger." However, Herle disclosed that this was only an outward show, that Lesley's servant and Barthlett had had "secrett accesse unto hym, yett with som difficultye or they cowd com to hym."45 Furthermore, Barthlett's frequent visits furnished Herle with intelligence from Lesley's followers. Having wormed his way into Barthlett's confidence, on 11 April Herle was able to inform Burghley of the imminent arrival of potentially malfeasant Scottish conspirators:

His opinion is such of me as he is to perswaded to any thing tellinge me of two Scottish Shipps belonginge to Fife, who vale downe this tyde to Blackwall \& might seme by him as though there were some partye or some matter in them which is worth the searche. 46

Herle thus enlarged the scope of his intelligence beyond the Marshalsea compound. Despite his confinement, he had access to time-sensitive and potent oral intelligence, information that he converted to written format for communication outside the prison walls.

The strategies for circumventing surveillance were not limited to controlling or diverting the circulation of letters. Papers had to be secreted in diverse places and often hidden from random searches by the prison staff. Searches of Herle's prison chamber, however, may have been intended as a convenient and inconspicuous method for transmitting letters to Burghley:

I have copyed owtt mi Lord, the Cipher butt it was nott abowtt me when those that cam which your Lord sent to me, to whom I made grett difficultye to delyuer ani writeng, the more to cover mi delyng, having ment for that I never cowd close up Charles letter, to have broken it in ii or iij parts, yett in suche sort as they might well have bin peced agayn together. 47

Herle was also aware of the strategies used by the supposed plotters to conceal correspondence and other material. Speaking of Bailly, Herle suggested that he be searched: "It may plese your Lord to serche his cap well, and that I may know (yf your Lord so vowchesaffe) whatt writengs were fownd abowtt hym." ${ }^{8}$ Moreover, Herle was not

45. Herle to Burghley, 29 April 1571 (TNA, SP 53/6/53, fol. 89r).

46. Herle to Burghley, 11 April 1571 (BL, MS. Cotton Caligula.C.iii, fol. 62r).

47. Herle to Burghley, 26 April 1571 (BL, MS. Cotton Caligula.C.iii, fol. 68r-v). This letter suggests that Burghley may have entrusted Herle with the task of copying the letters before delivery to Lesley or Bailly. Here, Herle may be saying that he has ripped the letter into pieces to prevent it from being read in its entirety.

48. Herle to Burghley, 27 April 1571 (TNA, SP 53/6/51, fol. 87r-v). 
reluctant to exploit such opportunities to ensnare his targets. He reported to Burghley a request by Lesley that Herle might soon deliver "som monney sherts and suche other necessaryes as [Bailly] wanted," darkly noting that among these items "som secrett wrytengs or discovery of their mynds" might be concealed. 49 Bailly took no such risks, however. The elusive cipher that Herle had been placed to extract-the one in which Ridolfi's letters to Mary had been written-was not evident in any of his letters directed to Lesley, as Herle and Burghley discovered to their chagrin. One of the suspected pirates originally indicted with Herle by the Privy Council, John Poole, discovered and revealed to Herle that Bailly had memorized up to four ciphers and was confident that the cipher encrypting the correspondence seized in his portmanteau at Dover in early April would not be cracked.50 It would take more serious measures on behalf of the Elizabethan authorities to obtain this information directly from Bailly later that spring. In late April, Herle having failed to persuade him to release any information about the cipher, Bailly was removed to the Tower of London, where he was tortured on the rack and later imprisoned in a cramped cell, only four feet square..$^{51}$

During his time in the Marshalsea, Herle regularly reported his discoveries to Burghley, both through letters and during personal visits. It is not clear whether his personal access to Burghley was overt, in the guise of "examination" or "interrogation" to foil counter-surveillance, or whether it was conducted secretly. Herle described in detail how a person might come unobserved to Burghley:

Touching Malachias, he shall wryte vnto your Lord to desire that he may com to your presence for so he hath entreated of hym self before, alledging that he hath somwhatt to say vnto your Lord wherupon your Lord sending for hym secrettly by the back waye, with gentillnes he is to be won. ${ }^{52}$

It is possible that Herle was able to deposit and collect intercepted letters directly to and from Burghley, in addition to planting them in his chamber for collection during searches by the keeper, who would have had to collaborate in the enterprise. "Routine" searches of Herle's chamber by the keeper or his officials could produce letters that could then be forwarded to Burghley, a procedure that would generate a minimum of suspicion. But regular searching was neither particularly convenient nor

49. Herle to Burghley, 18 April 1571 (BL, MS. Cotton Caligula.C.iii, fols. 176v-77r).

50. Herle to Burghley, 27 April 1571 (TNA, SP 53/6/51, fol. 87r).

51. The cramped cell was the infamous "Little Ease." Herle was also removed to the Tower of London, probably in order to try to continue the communication system, but no letters survive to indicate that he had any more contact with Bailly. A single letter survives from his incarceration in the Tower, an account of a conversation held with Dr. Rodrigo Lopez; Herle to Burghley, 17 May 1571 (BL, MS. Cotton Caligula.C.iii, fols. 82r-85v.

52. Herle to Burghley, 11 April 1571 (TNA, SP 53/6/37, fols. 64r-65v). 
subtle, given that the reason for Herle's imprisonment would have been kept deliberately vague to his guards as well as fellow prisoners. Frequents searches might have proven advantageous nonetheless: they could help Herle explain the delay in his delivery of letters while they were being copied and deciphered. Around 26 April Herle revealed that his cell had been searched in a letter to Lesley:

I am this morning comitted to Close prison for Charles Causes and am charged with heavy Irons being searched for writings. But as god would whiles I was put a parte \& they sekeing an other Chamber I brake up Charles letter as ye se and put it in a darke Chinck. 53

Lesley, expecting the letter from Bailly and concerned about the delay, was perplexed and angry as to why Herle had failed to come through, challenging "I mervayle that you did keepe such letters beside you so long." 54 Herle had plainly held the letters back so that he could copy the contents, perhaps waiting for their collection by the keeper during a random search of his prison cell, or delivering them personally to Burghley during one of his frequent "examinations." Personal interviews with Burghley or other government ministers were the best way to convey information, as the meetings could be presented as informal interrogation. Safer than letters, which could be perused by enemy eyes (which was, after all, the point of Herle's being planted in the Marshalsea), a visit moreover provided Herle with valuable access to his patron. Herle noted that he had urgent news to impart and was ready to fit into Burghley's busy schedule:

I have mi Lord browght this matter to a full issue, desirows your Lord wold vowchesaffe to appoint me a certain tyme when to make repport therof, which reqwires spede, if your weighty affayres wold permitt the same, yett hoping your Lord doth vnderstand by $\mathrm{mr}$ Blithe that I have bin there sondry tymes, which may excuse ani negligens that otherwise might be imputed to me. 55

The importance Herle placed on these personal visits and the frequency with which he requested them onfirms his inclination to impart information by "mowth." Not only was this method of communication more secure, but it also provided the interaction Herle required to retain his client status with Burghley. The intimacy of speech, exchanged in a private, closed room, combined with the anonymous and clandestine nature of his task, would enhance his bond with Burghley. Herle longed for this access, writing to Burghley, "Prayng God for your Lords prosperity, and wisheng if I shold com ani more vnto yow ye wold prescribe when and how, for mi open repayre to your

53. Herle to Lesley (BL, MS. Cotton Caligula.C.iii, fol. 65r-v).

54. Lesley to Herle, 27 April 1571 (BL, MS. Cotton Caligula.C.iii, fol. 7or).

55. Herle to Burghley, ca. 10 April 1571 (TNA SP 53/6/36, fols. 62r-63v). 
Lord may hinder gretter thyngs than ar yet expressed." 56 Communicating verbally also gave Herle a brief interlude away from his prison cell. These letters tell of a desire to go beyond the epistolary medium, to have face-to-face contact. For Herle, the possibility of an audience during his imprisonment hinted at the promise of his future release. Moreover, the comfort and solace provided by human interaction would ease the hardship of incarceration.

\section{\&્S}

Fundamental to Herle's strategy with Burghley was the emphasis on his cordial and client status with his patron. In times of liberty, Herle was keen to parade his important friendships and alliances in intelligence letters designed to be read by others. His key tactic was to combine a tantalizingly sensitive item of news or intelligence with a request for preferment or assistance in stalling his debts. 57 In this way, Herle was positioning himself in a visible network of clients whose "service" rested on the transfer of information. The need to make this patron-client relationship visible was only sharpened by the secrecy of the intelligence exchanged, an activity that was largely hidden from view; during his confinement in the Marshalsea, Herle must have found it frustrating that he had to conceal this intimate relationship with his patron. In his letters directed to Burghley during this period (the only other correspondent in Herle's surviving letters from this episode is Lesley), Herle's claims of obligation and service were effusive, frequently emphasizing his duty and fidelity. He re-affirmed his "delight" in performing loyal service, assuring Burghley and other potential readers of his continued allegiance to the state despite his dealings with the suspicious conspirators in the Marshalsea:

Comending to your Lord mi hard Case, desirows to spend mi life in ani thing her Maiestie and your Lord wold employe me and bicause there is nothyng more dere vnto me than to be restored to good oppinion and name, I humbly desire your Lord to be mi good Lord therin, which may be an argument that while I esteme that dutye, mi reverens to god and mi Prince cannott decaye nether can I committ ani vncomly thyng otherwise..$^{8}$

56. Herle to Burghley, 16 April 1571 (TNA, SP 53/6/40, fols. 69r-70v). For similar bids to win access to the presence of a significant figure during imprisonment, see Schneider, Culture of Epistolarity, 106.

57. See, for example, Herle to the Earl of Leicester, 21 March 1582 (TNA, SP 83/15/73, fols. 163r-66v), regarding the assassination attempt on William of Orange in Delft; Herle to Burghley, 15 November 1583 (BL, MS. Lansdowne 39, fols. 189r-92v), about conspirators in London and the French embassy; and Herle to Burghley, 26 February 1573 (BL, MS. Lansdowne 16, fols. 98r-99v), concerning Herle's mistrust of Jerome de l'Huillier, Seigneur de Maisonfleur, an emissary of the Duke of Alençon.

58. Herle to Burghley, 10 April 1571 (TNA, SP 53/6/36, fols. 62r-63v). 
Herle's strategy, to advertise his relationship with his patron in letters to his patron, which he presumed could be broadcast to important members of the Privy Council and beyond, was bound to be foiled by the strict secrecy surrounding his prison activity. 59 Still, operating on the assumption that at least a few important figures might eventually see the letters affirming his place in a crucial information network, or hear about his loyal service to the Crown, Herle gave emphatic protestations of humble duty and service:

But yet vouchsafe my good Lord to commend my humble minde to the Quenes Maiesty that yet one day I may be the more able by her goodnes to any greater commandement wherein I desire to ymploy mi life and all the rest And herein that you will likewise enterteyne a good opinion of me with Master Comptroller, whose care is greate of me, and yet hath not heard from me in a great space Lastly I beseeche your Lordship to remember your good speech of me if you see the Bishop of Salisbury. 60

Herle was keen both to widen his network of important figures and contacts (his reference to "Master Comptroller" and the bishop of Salisbury reminding Burghley of Herle's ancillary patronage network outside of the prison walls) and to refer to a time in the future after the Marshalsea project of deciphering Bailly's correspondence had ended. Herle's liminal status within the confines of the Marshalsea, observing, reporting, and to a certain extent enacting deviant behavior, left him little opportunity to operate within a legitimate social sphere, but he hoped that under the aegis of Burghley and the queen, he might serve at some future date. ${ }^{61}$

59. In later years, Herle would ensure maximum coverage by sending copies of his politically sensitive letters to the Earl of Leicester and Walsingham, as well as Burghley.

6o. Herle to Burghley, 1 May 1571 (BL, MS. Cotton Caligula.C.iii, fols. 71r-72v). "Master Comptroller" may be Sir James Croft, appointed 1571, ODNB, article 6719. The Bishop of Salisbury at this time was John Jewel; see ODNB, article 14810.

61. For legitimate social identity arising from qualifying participation in social roles, see Stephen Greenblatt, Renaissance Self-fashioning: From More to Shakespeare, and ed. (Chicago, 2002), 42. Upon his release from the Tower of London (where he was moved, probably to follow Bailly, although none of Herle's letters relating to this plot survive from this location), Herle's "service" remained focused on the surveillance of conspirators, until he returned to semi-official diplomatic work. Charles Bailly remained in the Tower until brokering his release by offering to spy for Burghley; he was banished from England in November 1572. Shuttled between close prison in the infamous "Little Ease" and a cell in the Beauchamp Tower, Bailly whiled away the long months of imprisonment by carving his mark into the walls. One inscription (quoted in Edwards, Marvellous Chance, 80) reads:

\footnotetext{
Wise men ought circumspectly to see what they do;

To examine before they speak;

To prove before they take in hand;

To beware whose company they use;

And, above all things, to whom they trust.
} 
The opportunity for the exhibition of his public bond with Burghley decreased during Herle's ongoing incarceration for piracy, and this likely motivated him to capture and even heighten the drama of the moment in his letters. Seeking to convince Bailly and Lesley of his trustworthiness through persuasive speech and performance, and Burghley of his loyalty through his textual account of such persuasion, Herle left to the modern reader only a textual record of his attempts to penetrate the conspiracy. Yet these engrossing letters are a testament to his remarkable style and daring, as the extraordinary details unfold on each page of faded, tattered manuscript.

Herle's fervent participation in this episode nonetheless raises questions of his integrity and the credibility of his intelligence: might the ability to "spin" a yarn and to assume the identity of a malefactor harm his position as an information-gatherer for the Elizabethan government? It is here that we encounter the crucial problem for scholars using intelligence letters as evidence, which is, indeed, closely related to the problem early modern policy-makers faced. Could an agent's accounts be trusted? Political heavyweights like Burghley were forced to rely on largely uncorroborated data from unreliable agents. Add to this the idiosyncratic methods of transmission befitting the secret intelligence, and a picture emerges of an administration rich with intelligence sources yet unable to rely on intelligence so gathered. More than four hundred years later, the modern reader is similarly hampered by the interruptions and silences in the archives when deciding whether the plan to intercept Bailly's letters to and from Lesley had its genesis in Herle or Burghley. I conclude that the scheme was jointly designed and developed, Herle's offer of service felicitously coinciding with Burghley's intelligence from Walsingham that Bailly would be crossing the channel with illicit material and ciphered letters.

\section{旡}

What does this sequence of letters contribute to the study of early modern prison writings and Elizabethan intelligence operations? Herle's letters offer in remarkable detail a window into his development and performance of the role of prison spy in the Marshalsea. We can sense rather than see the shifting, shadowy movements of Burghley as puppeteer, capitalizing on the frantic offers of service from a desperate prisoner and the tacit complicity of the Elizabethan administration in formulating these kinds of traps and methods of surveillance (and counter-surveillance, and even countercounter-surveillance). Throughout the sequence of letters, we can observe Herle permitting himself to revel in the retelling of his more sensational encounters with the alleged conspirators. Nowhere else in the substantial corpus of extant letters is his language quite so indulgently florid or melodramatic, and the level of detail here goes some way toward reconstructing the rudimentary system of information exchange through the prison's walls. The secretion of letters in "dark chinks" in the porous walls or their concealment in items of clothing also suggests that the minis- 
ters, keepers, and lower-level prison guards tolerated the exchange of information, supposing (often correctly) that if intercepted, the letters or documents might yield incriminating evidence.

Herle's letters afford an extremely rare interior view of both the Marshalsea compound and the government activity operating in the background of the affair. His complicit participation in the attempt to discover the cipher from Bailly and Lesleyand his detailed and dramatic account of that participation-provides unique access to a system of information-exchange usually obliterated from the historical record. Prisoners would normally attempt to keep their clandestine methods of transmitting letters entirely hidden from the prison authorities and higher bodies of government, but Herle opens the process to view. His graphic rendering of the correspondence networks within the prison environment and between it and the outside reveals the channels of communication created by and available to Tudor prisoners, as well as the intervention by the Elizabethan authorities to appropriate and mobilize these channels for espionage. The prison wall, metaphorically leaky and physically ramshackle, is dichotomous: a site of enclosure and a visible barrier, but one that can be penetrated and through which subversive material can be exchanged.

Above all, though, in reading Herle's letters we can detect his attempt to raise his cliental status by harnessing the features of his imprisonment to get close to Burghley. The catalogue of requests in Herle's letters makes plain his desire to see Burghley in person, to begin to salvage and reconstruct the patron-client relationship. Crucially, Herle senses that this must occur outside the prison walls if he is to reemerge and participate legitimately at a later date in the social circle from which he has fallen so far. Herle's letters (that this is a unidirectional correspondence is likely) reveal the ad hoc and improvised methods Burghley's administration employed for dealing with situations of acute political importance and sensitivity. From Herle's point of view, however, something more definite was necessary: he transmuted his initial sojourn in the Marshalsea into a series of textual vignettes that could potentially enhance and further his patronage prospects. Despite this strategic approach to the forces shaping English policy, he continued to languish at the margins of the Elizabethan polity-no doubt partly as a result of the ease with which he turned his hand to duplicitous activity - until the later decades of Elizabeth's reign. But Herle's "service," based upon the surveillance of a conspiracy against the Elizabethan regime, was far more useful to the polity when situated at the limits of the social landscape.

I am most grateful to Rosanna Cox, Lisa Jardine, William Sherman, and Matt Symonds for their helpful advice during the preparation of this article.

contributor's note overleaf 
ROBYN ADAMS is the Senior Research Officer at the Centre for Editing Lives and Letters (CELL) at Queen Mary, University of London. She is the editor of two online projects at CELL, "The Letters of William Herle" and "The Diplomatic Correspondence of Thomas Bodley, 1585-97." With Nadine Akkerman, she is the coeditor of the correspondence of Elizabeth Stuart, Queen of Bohemia (forthcoming). 